\title{
PEDAGOGY
}

\section{Problems of data protection competence formation}

\author{
V. Artemov, A. Rusnak \\ National Academy of the Security Service of Ukraine \\ Paper received 07.03.19; Accepted for publication 20.03.19.
}

\begin{abstract}
https://doi.org/10.31174/SEND-PP2019-198VII80-01
\end{abstract}
\begin{abstract}
. the analysis of the peculiarities of the formation of professional competence, pedagogical conditions and the model of training specialists for data protection, as well as the formation of deontologically oriented thinking has been carried out. It has been determined that deontology for specialists in data protection should penetrate as far as possible all classroom and non-auditorium classes. The pedagogical model, in addition to the content part, must have an activity component, which permits the formation of competence as a sequence of definite steps. An institution that prepares specialists for data protection is not bound to interrupt communications with their graduates, helping them in professional adaptation and professional development in the form of, for example, additional training, participate in the periodic certification of specialists in their profile, the results of which make changes to the content, methods its formation and practical realization.
\end{abstract}

Keywords: personal data protection, professional competence, pedagogical conditions, pedagogical model, deontology, deontological principles.

The problem setting. Data protection is the most important problem of our time within the entry into the information society. There are different types of threats and different ways to protect against them. The most urgent problem is the unauthorized access data protection. In today's world, some of the general data becomes sensitive to human rights and freedoms, to the state and society security. Some of the sensitive data is subject to classificate, and their protection is carried out in accordance with the laws on state secrets, industry and departmental norms. A vast area of general data belongs to the category of unclassified, but sensitive data. In the context of globalization, this data area is constantly expanding. The protection of such data requires more and more qualified specialists. The training of specialists to protect such data constitutes a pedagogical problem.

The problem essence is the specialists to protect such data, in addition to deep technical knowledge, must possess high moral qualities. In particular, much attention is paid to the issues of social responsibility and moral debt in the General Data Protection Regulation (GDPR), adopted by the EU in 2016 [1].

The key concepts of the problem are the professional competence, pedagogical conditions and pedagogical model.

The analysis of recent studies and publications. As to competence, a long discussion about its nature was held in the research community. Despite the fact that Ukraine has adopted a law on higher education, which clearly defines competence [2], this debate continues. Among recent publications, it should be noted the Ukrainian researchers Bolotnikova I.V. [3] and Kravchenko S.O. [4] papers. But in these publications, the emphasis is on the cognitive component, and the moral component remains "in a shadow".

Pedagogical conditions in the educational community into the latest research publications are perceived either as the circumstances of the learning process, or as a set of measures aimed at improving the effectiveness of pedagogical activity, or as a reflection on the possibilities of the educational environment. It should be noted that this term finds its application mainly in the post-Soviet educational space. Among the recent publications are the papers of Lugovoi V.I. [5] and Zavatskaya N. E. [6]. But the work directly related on the formation of pedagogical conditions for the training of data protection specialists in the available literature was not found.

The pedagogical model is a powerful tool for problemoriented, cognitive, situational and computer-based learning. The pedagogical model can be perceived as a exemplar or as an instruction for teaching [7]. The extensive bibliography [8] is devoted to the problems of constructing and applying pedagogical models [8], in which the base for constructing a pedagogical data protection training model is displayed. Unfortunately, most of the models presented there are oriented towards obtaining knowledge in the field of technical protection of information but not the formation of the moral character of a specialist.

As a result, it should be noted that in spite of the existence of sufficiently profound research in terms of professional competence, pedagogical conditions and pedagogical models, it is still not enough to solve the problem of the formation of data protection specialists, sufficient scientific and theoretical grounds and practical recommendations

The objective of this paper is to discus the problem of the professional competence, pedagogical conditions and data protection specialists training mode formation.

Research methods. In the process of the problem of the data security communicative competence formation studying, theoretical methods were used, namely: a systematic approach, analysis of research publications and normative documents, interpretation of survey results; synthesis of practical recommendations on the results of research.

The results and discussion. In accordance to the Ukraine "On higher education" Law (Art. 1, clause 13), competence is a dynamic combination of two components: knowledge and practical skills, as well as ways of thinking, professional, ideological and civic qualities, moral and ethical values [2]. As a result of the research, it was revealed that with respect to the data protection spe- 
cialists training system, the second component of competence - the worldview component - should be supplemented and, in addition, it is necessary to introduce the third component - the personal component - for the data protection sphere.

Specificity of data protection requires employees to perceive their professional obligation as fulfilling a high spiritual duty. Remaining alone with his duties, risks and threats, and not having a strict controller behind him, he must be guided solely by the requirements of professional and civic duty. The theoretical basis for the formation of this attitude to the profession is deontology - the doctrine of the morality problems [9]. In practice, deontology usually opposes utilitarianism [ibidem]. Utilitarianism suggests what can be done under certain conditions, and deontology - which can not be done under any circumstances. It should be noted that deontology has already penetrated into the field of data protection. This is evidenced by the adoption of the deontological charter by the leading French company for the protection of personal data AFCDP [10]. According to the company's rules, each employee must pass the certification and sign the deontological charter.

As for the third - the personal component of competence, it follows from the results of the research conducted, it should provide the flexibility, creativity and, at the same time, perseverance, endurance, discipline from the data protection specialist.

Pedagogical conditions, in our opinion, are conditions that, on the one hand, ensure the competence formation, and on the other hand, are achieved by pedagogical means. Pedagogical conditions can not be replaced by pedagogical goals, as is often found in pedagogical research publications [11]. In our understanding, an important pedagogical condition for the professional competence formation of data protection specialists is the creation of a special atmosphere, call it deontological sense of justice, based on deontological thinking, whereby the professional realizes his duty when the objective duties in ideas, feelings, beliefs, motives, which ensures sustainable professional behavior.

In our opinion, for the formation of deontological thinking, it is not enough to introduce into the training program the data protection specialists the deontology course as a section of ethics. In our understanding, deontology for this category of professionals should permeate, if possible, all curricular and extracurricular activities, reflect in the faculty behavior. The student should understand that to study and master a particular subject, to act in a certain way, he must understand the fulfillment both his professional and civic duty.
The third key concept is the pedagogical model. Most of the well-known pedagogical models have a substantial character, they are a kind of pattern that serves to understand the author's ideas. In most, they have a static nature, even if they represent stages. The purpose of such models is to display the context and methods of its construction [12]. In our understanding of the data protection communicative sense formation, the pedagogical model, in addition to the content part, should have an activity component that allows to represent the formation of competence as a sequence of certain steps.

The proposed model at the first stage provides for the formation of deontologically oriented thinking and deontological environment in the educational space and professional environment. This stage involves conducting seminars and trainings with leading staff and faculty. The next stage is the construction of educational content in the educational environment. The model provides for the formation of educational content on the basis of value, including deontological, principles, as well as taking into account the base of technological and research knowledge. Based on the generated content, curricula and programs are created. Next - the implementation of content in the form of auditor and extracurricular activities. They are implemented on the basis of the principles of integrating the processes of education and upbringing. Formation of the deontological component of competence is not limited to teaching a separate course.

In accordance with the proposed model, deontological principles permeate all disciplines. The educational institution does not interrupt communication with its graduates, helping them in professional adaptation and professional development in the form of, for example, additional training. The institution also participates in the periodic certification of specialists of its profile, which results in changes in the content, methods of its formation and practical implementation. Preference is given to active and interactive methods.

Conclusions and prospects for further research. Data protection is an urgent problem of the present day, requiring permanent improvement of the professional competence of personnel engaged in this field.

In this regard, the problem of the formation of professional competence of specialists to protect data, the definition of its pedagogical conditions and the model of preparation come to the fore. The modern specifics of data protection require the perceptions by the data protection employee their professional responsibility as fulfilling a high spiritual duty. And so the proposed model have been provided for the formation of deontological oriented thinking and deontological environment in the educational space and professional scope.

\section{ЛІТЕРАТУРА}

1. General Data Protection Regulation (2018) Available at // https://gdpr-info.eu

2. Закон України «Про вищу освіту» (2018) Available at //zakon.rada.gov.ua/laws/show/1556-18

3. Болотнікова, І.В. (2008). Професіоналізм та професійна компетентність як складові психічної зрілості особистості. Актуальні проблеми психології, 26 ( 8), 3-7.

4. Кравченко, С.О. (2018).Узагальнення сутності дефініції «дослідницька компетентність». Young Scientist, 54 ( 2), 32-39.

5. Луговий, В.I. (2009). Європейська концепція компетентнісного підходу у вищій школі та проблеми іiі реалізації в Україні. Педагогіка і психологія, 63 (2), 13-25.

6. Завацька, Н. Є. (2017). Психологічні умови формування адаптивних можливостей студентів вищих навальних закладів гуманітарного профілю: А Monograph. Сєвєродонецьк, Украина: вид-во СНУ ім. В. Даля, 176.

7. M. T. Gumbo; J. P. Williams. (2012). Technology teachers' pedagogical content knowledge: A Monograph. Available at 
https://www.abebooks.com/9783659225314/Technologyteachers-pedagogical-content-knowledge-3659225312/plp

8. Дубасенюк, О.А. (2008). Концептуальні моделі педагогічної освіти: наукові пошуки та здобутки: Монографія. Житомир: Видво ЖДУ ім. І. Франка, 8-29.

9. Максимов, Л. В. (2001). Деонтология: Новая философская энциклопедия. Москва, Россия: Мысль. ), 314.

10. AFCDP's Charter of Deontology for Data Protection Officers. (2018). Available at //
https://www.afcdp.net/IMG/pdf/afcdp_-

_dpos_charter_of_deontology.pdf

11. Майборода, В.К. Артемов, В.Ю. (2013) Сутність і зміст деонтологічної складової компетентісного підходу в системі вищої освіти. Науковий вісник Миколаївського державного педагогічного університету ім. В.О. Сухомлинського.42(1), 144-148.

12. Болотов В.А. (2013). Компетентностная модель: от идеи к образовательной программе. Педагогика. 85(10), 8-14.

\section{REFERENCES}

1. General Data Protection Regulation (2018) Available at // 8. Dubasenjuk, O.A. (2008). Konceptual'ni modeli https://gdpr-info.eu

2. Zakon Ukraïni «Pro vishhu osvitu» (2018) Available at //zakon.rada.gov.ua/laws/show/1556-18

3. Bolotnikova, I.V. (2008). Profesionalizm ta profesijna kompetentnist' jak skladovi psihichnoï zrilosti osobistosti. Aktual'ni problemi psihologiï, 26 ( 8), 3-7.

4. Kravchenko, S.O. (2018).Uzagal'nennja sutnosti definiciï «doslidnic'ka kompetentnist'». Young Scientist, 54 ( 2), 3239.

5. Lugovij, V.I. (2009). Evropejs'ka koncepcija kompetentnisnogo pidhodu u vishhij shkoli ta problemi $\dddot{i}$ realizaciï v Ukraïni. Pedagogika i psihologija, 63 (2), 13-25.

6. Zavac'ka, N. C. (2017). Psihologichni umovi formuvannja adaptivnih mozhlivostej studentiv vishhih naval'nih zakladiv gumanitarnogo profilju: A Monograph. Severodonec'k, Ukraina: vid-vo SNU im. V. Dalja, 176.

7. M. T. Gumbo; J. P. Williams. (2012). Technology teachers' pedagogical content knowledge: A Monograph. Available at https://www.abebooks.com/9783659225314/Technologyteachers-pedagogical-content-knowledge-3659225312/plp pedagogichnoï osviti: naukovi poshuki ta zdobutki: Monografija. Zhitomir: Vidvo ZhDU im. I. Franka, 8-29.

9. Maksimov, L. V. (2001). Deontologija: Novaja filosofskaja jenciklopedija. Moskva, Rossija: Mysl'. ), 314.

10. AFCDP's Charter of Deontology for Data Protection Officers. (2018). Available at // https://www.afcdp.net/IMG/pdf/afcdp__dpos_charter_of_deontology.pdf

11. Majboroda, V.K. Artemov, V.Ju. (2013) Sutnist' i zmist deontologichnoï skladovoï kompetentisnogo pidhodu v sistemi vishhoï osviti. Naukovij visnik Mikolaïvs'kogo derzhavnogo pedagogichnogo universitetu im. V.O. Suhomlins'kogo.42(1), 144-148.

12. Bolotov V.A. (2013). Kompetentnostnaja model': ot idei k obrazovatel'noj programme. Pedagogika. 85(10), 8-14. 